\title{
Yuriy Kondratyuk's Name Was Written in Her Heart
}

\section{Gennadii Aliaiev}

Doctor of Philosophical Sciences, Professor, Poltava Yuriy Kondratyuk National Technical University (Poltava, Ukraine)

E-mail: gealyaev@gmail.com

ORCID: 0000-0001-6713-2014

\section{Ludmyla Cherednyk}

PhD in Philology, Associate Professor, Poltava Yuriy Kondratyuk National Technical

University (Poltava, Ukraine)

E-mail: ludmila.cherednik@gmail.com

ORCID: 0000-0001-9589-8041

\section{Victor Chernyshov}

PhD in Philosophy, Associate Professor, Poltava Yuriy Kondratyuk National Technical

University (Poltava, Ukraine)

E-mail: christ.philosopher@gmail.com

ORCID: 0000-0002-0960-8464

The paper is to render homage of memory to a historian, tireless explorer of the local history, researcher of the biography and works of Yuriy Kondratyuk Dr. Nadiya Kocherha. The paper represent facts, telling the story of rehabilitation Yuriy Kondratyuk's (real name - Alexander Shargey) good name as scientist and inventor, and the popularisation of his ideas at Poltava Yuriy Kondratyuk National Technical University.

Keywords: Yuriy Kondratyuk, history of astronautics, local history, cosmonautics and aeronautics (aviation) in Poltava, philosophy of cosmism

Received: July 29, 2018; accepted: August 15, 2018

Philosophy and Cosmology, Volume 21, 2018: 159-166

DOI: $10.29202 /$ phil-cosm/21/17

(C) Aliaiev, Gennadii, 2018

(C) Cherednyk, Ludmyla, 2018

(C) Chernyshov, Victor, 2018 


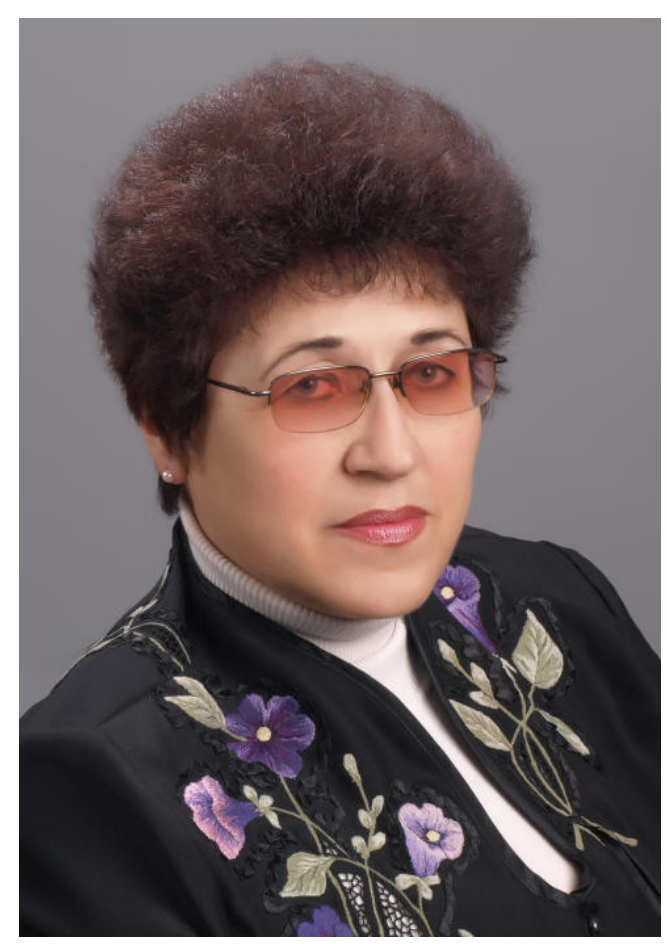

On Friday 22 June 2018 our dear colleague, friend, pedagogue and established scholar, active member of Poltava cultural and social life, loving and beloved mother and grandmother, a person of big heart Nadiya Kocherha passed away after a brief illness.

Nadiya Konstyantynivna Kocherha (née Korobeynyk) was born in village Kruta Balka, Novy Sanzhary District, Poltava Region, on 13 April 1950 to her parents: father - Kostyantyn Oleksandrovych and mother - Mariya Hryhorivna. From her mother - a humble village school teacher (who taught Russian language and literature) - she adopted the great love for books and learning, culture, history of her native land, the inexhaustible aspiration for discovering and knowing everything new and previously unknown. She read extensively since her childhood. Her mother recollected that little Nadiyka had read all the books not only in the school library, but also in the village public library. Throughout her life, Nadiya Konstyantynivna Kocherha was a great lover of books; keeping abreast of new literature she had always surprised her colleagues with her erudition.

In 1973 Nadiya Konstyantynivna graduated from Historical Faculty of Poltava Volodymyr Korolenko State Pedagogical Institute; later, having accomplished her postgraduate studies at Kyiv Taras Shevchenko State University, she successfully defended her PhD thesis in history. Since 1978 the locus of her pedagogical and creative career had been Poltava Construction Engineering Institute that is now known as Poltava Yuriy Kondratyuk National Technical University. Having gradually advanced the steps of professional ladder, in 1991 Dr. Nadiya Kocherha became head of the department of Ukrainian Studies: it was the first department of such kind in Ukraine, and it had been created on her initiative. Dr Kocherga's active position that she had always held in the life of the university predestined her promotion to the position of pro-rector in humanitarian aid and educational work (1997-2004). In 2015 Dr. Kocherha resigned from the position of head of department, but continued to work henceforth in the 
position of associate professor, and also performed her duties of Rector's adviser. Her selfless labour in the field of education had been highly appreciated and rewarded with Certificate of Honour from The Verkhovna Rada of Ukraine, Certificate of Honour from The National Academy of Sciences of Ukraine and The Little Academy of Sciences of Ukraine; she was decorated with honorary titles of High Achiever of Education of Ukraine, Veteran Teacher of Ukraine, and many other awards and decorations. Dr. Nadiya Kocherha was laureate of regional Makarenko prize, Kotliarevs'kyi prize, and Korolenko prize for workers in the culture and education area.

Dr. Kocherha's true passion was the museum work. Since 1985 she performed the duties of Institute museum director. The museum exposition had already existed, but with her effort it was cardinally reshaped, considerably supplemented and expanded, which enabled in 1998 — by then already — the university museum (in 1994 Poltava Construction Engineering Institute was transformed into Poltava Technical University) to gain the statues of People's museum. Present exposition of the museum represents in an organic unity all of the two hundred years of Poltava tradition of education, starting from the foundation of Institute of Noble Maidens (1818), the buildings of which — that had been designed by a reputed Russian architect Louis Charlemagne, and constructed in 1832 — in 1930 became home to Poltava Agricultural Construction Engineering Institute of which the present Technical University that bears the name of one of the most celebrated pioneers of astronautics Yuriy Kondratyuk is the immediate successor.

Dry lines of nearly official obituary can barely reflect the role that Dr. Kocherha played in the university life. There can scarcely be found any established teacher or administrator in the university who had never asked her for help or assistance doing a text proof-reading or corrections with respect to Ukrainian grammar, an excursion around the University museum or historical and cultural sites of Poltava and Poltava region for conference participants or guests of the University, for her aid in organising student self-government in a faculty or campus life, and many other various requests. She had never refused. Dr. Kocherha herself had always been an enthusiast organiser and factually founded a number of university traditions: conducting of regular thematic educational events with students, she had also developed a conception of educational work that laid the foundation stone for creating University student parliament in the late 1990s; and the words of the University hymn is also a piece of her invention and the work of her genius.

Aforesaid merits and achievements however do not directly connect Dr. Nadiya Kocherha with the area of philosophy and cosmology, unless the name of the University that had become dear to her. But as a matter of fact, the name of Yuriy Kondratyuk our University bears, to a great extent, thanks to Dr. Kocherha; as well as her own name today can rightfully be listed among the names of scholars whose continuous effort enabled Yuriy Kondratyuk (Alexander Shargey) to take the place - he had truly deserved - in the history of science and technology, beside the other famous theorists of space travel science and engineer-inventors.

As a researching historian Dr. Nadiya Kocherha had a wide range of interests that laid primarily in the field of local history. Besides the enormous work in area of the history of Poltava educational institutions that had already been mentioned above, another focus of her studies was on the cultural history of Poltava region: e.g., from her pen (in collaboration with Dr. Viktor Revehuk) flowed two books on Volodymyr Korolenko and his life in Poltava [Revehuk \& Kocherha, 2003; Revehuk \& Kocherha, 2014]; she also wrote about painters Vasiliy Volkov and Ivan Zaytsev, who taught at Poltava Institute of Noble Maidens and Poltava Cadet Corps, and on Poltava connections of Volodymyr Vernadskyi, etc. 
Poltava however is not only — as it is usually being considered — one of spiritual and cultural centres of Ukraine; at different times it was home to a number of scientists and engineers in the area of aeronautics and astronautics. Among the first here should be mentioned the name of Oleksandr Dmytrovych Zasyad'ko, who was an artilleryman and missile constructor - first his missiles had been tested in 1818; a crater on the far side of the Moon bears his name since 1976. A few years ago, there was a paper published in Philosophy and Cosmology, titled Oleksandr Dmytrovych Zasyad'ko: a Descendant of Zaporozhye Cannoneer at the Head of Rocket Technology by Dr. Nadiya Kocherha [Kocherha, 2010]. The inventor of the knapsack parachute Hleb Kotelnikov, rocketeer Yuriy Pobedonostsev, constructor of space rockets Volodymyr Chelomey, and a number of other theorists and practicians of the space rocket area housed in Poltava. It is no accident that on academic Valentyn Hlushko's initiative the Museum of Aviation (aeronautics) and Cosmonautics (astronautics) founded in Poltava (it opened its doors to the public in 2001) [Pistolenko, 2009; Pistolenko, 2016]. However, among all these names the name of Yuriy Kondratyuk that for a long time remained either almost unknown or covered with unfathomable mystery and tabooed had become a favourite one for Dr. Kocherha.

Thirst for knowledge brought Dr. Kocherha in 1980 to Poltava Volodymyr Korolenko State Pedagogical Institute to Yuriy Kondratyuk conference of Physico-Mathematical Faculty, organised under the guidance of D. Sc. in physico-mathematical sciences, Professor Oleksandr Panteleymonovych Rudenko. By the time, with Professor Rudenko's effort, there had been created a little Yuriy Kondratyuk museum (1980) at Poltava Volodymyr Korolenko State Pedagogical University; and in 1982 there was opened a memorial plaque with Kondratyuk's high relief and inscription: "A prominent soviet scientist and inventor, one of the first engineers of space travels Yuriy Vasilievich Kondratyuk (1897-1941) studied in this house at the Second Men's Gymnasium in 1910-1916" (more precise date of Kondratyuk's death, who volunteered for the army in 1941, and was killed in action in February 1942, had been fixed later).

Rehabilitation of the academic name - as much as the recovery of the real name and biography of Yuriy Kondratyuk - Alexander Ignatovich Shargey — had become a matter of concern for a number of interested people. However, Yuriy Kondratyuk was completely rehabilitated in his own fatherland only in 1970, after American Apollo had landed on the Moon (1968), having used his Lunar orbit rendezvous (LOR). Academics Valentyn Glushko, Yuriy Pobedonostsev, Boris Rauschenbach, and others wrote about Kondratyuk. An immense research work had been done by Kondratyuk's associate, who served with him in the same regiment, and later became a design engineer of Lavochkin design office Borys Ivanovych Romanenko; as well as one of Kondratyuk's cousins, and his first biographer Anatoliy Volodymyrovych Datsenko. Even today their works remain the most complete and important studies, representing Kondratyuk's life and works. The book The Star of Kondratyuk-Shargey by Borys Romanenko represents an engaging story of researches and rehabilitation of the truth about the prominent inventor [Romanenko, 1998].

It is only in 1980s became known that the author of book The Conquest of Interplanetary Space Yuriy Kondratyuk was not a native of Lutsk Hryhoriy (Yuriy) Vasyl'ovych, but a native of Poltava Alexander Ignatovich, and his real surname was Shargey. These circumstances, of course, in the first place predestined Dr. Kocherha's interest, as a researcher in Poltava local history, to Kondratyuk's unordinary personality, his destiny, and his fate. However, this interest had not been reduced to a purely academic desk study. Speaking without unnecessary fervour, we can say that Dr. Kocherha became a passionate propagandist of Kondratyuk's 
thought and ideas, she could be able to recognise in his thoughts and biography a powerful educative potency, and eventually related him with Poltava Technical University, coming to be the chief initiator and, so to say, the motor of conferring on Poltava Technical University the name of Yuriy Kondratyuk.

The University - formerly Poltava Construction Engineering Institute - has never been directly related with aeronautics and astronautics. It is notable however that it was a humanitarian scholar - a historian - Dr. Nadiya Kocherha who noticed that Yuriy Kondratyuk's engineer activities had been perfectly fit with the university profile. Kondratyuk undoubtedly was a talented inventor in area of construction engineering, technology and energetics: a cup for conveying elevator, the biggest wooden grain elevator "Mastodon", wooden pendant bridge, ferroconcrete tube tower, ferroconcrete tower-type pile driver, a project of the biggest wind power station on the mount Ay-Petri, and many other things: all those things were the works of Kondratyuk as a theorist of space travels, and all those things were the real embodiments of his earth philosophy [Romanenko, 1998: 27-28]. It was no accident that one of his manuscripts on the theory and practice of space flights Kondratyuk expressively called To Those, Who Will Read in Order to Build.

Another thread that connects Kondratyuk's name with the name of our university is his genealogy: the fact that his mother Ludmila Lvovna, née Schlippenbach, was brought up at Poltava Institute of Noble Maidens ${ }^{1}$. Thus three subjects, three histories interwove for the historian and explorer of the local history Dr. Nadiya Kocherha, which were not of a mere interest for her, but sank deeply into her heart and mind: Poltava, Yuriy Kondratyuk, and Poltava Institute of Noble Maidens. There began since then the years of unremitting toil, researches, new acquaintances...

In 1997 the centenary of Kondratyuk's birth gave a cause for international celebration according to the resolution issued by UNESCO. The first Yuriy Kondratyuk's academic biography by Anatoliy Datsenko and Vladimir Pryschepa [Datsenko \& Pryschepa, 1997], appeared in print in Moscow academic publishing Nauka. On Dr. Kocherha's initiative Anatoliy Datsenko visited Poltava Technical University to present his book on the Day of Cosmonautics (astronautics) 12 April 1997. On 21 June 1997 - in the day of Yuriy Kondratyuk's hundredth anniversary - according to decision of the Cabinet of Ministers of Ukraine his name was conferred on Poltava Technical University. Since then - again first of all thanks are due to Dr. Kocherha's effort - Yuriy Kondratyuk's name has become not merely a label or even a brand of the University, but it has rather become a particular moral reference point, an example of academic and humanitarian selflessness, the measure with which the university life is verified and adjusted. Annual student meetings and reunions on 12 April - on occasion of the Day of Cosmonautics, and on occasion of Yuriy Kondratyuk's anniversary that falls on 21 June have become traditional for the University, as well as the practice of academic conferences and round tables within the framework of Kondratyuk readings. In May 2017 there was held the international academic and practical conference Kondratyuk Innovations $21^{s t}-22^{\text {nd }}$, dedicated to Yuriy Kondratyuk's (Alexander Shargey's) one hundred and twentieth anniversary, in course of which a monument to the great inventor was unveiled in front of the university main building. And it is quite natural that the jubilee medals of the Academy of Sciences of Ukraine were presented not only to the immediate authors of the monument - its architect Andriy Konyuk and sculptor Valeriy Holub, - but also to the author of the idea - Dr. Nadiya Kocherha.

${ }^{1}$ By the way, on his mother's line, Alexander Shargey (Yuriy Kondratyuk) is a descendant of that ardent Schlippenbach, whom Pushkin mentioned in his Poltava: a Swedish baron, who fought in the Battle of Poltava in 1709, was captured, but afterwards having become a Russian general. 
On Dr. Kocherha's initiative the University developed and participated into the publishing activities about Yuriy Kondratyuk. The book Yuriy Kondratyuk (Alexander Shargey): the Son of Ukraine, the Son of Poltava by Anatoliy Datsenko had been published in 1997, and republished in 2000 under the aegis of the University [Datsenko 2000]. Anatoliy Datsenko also collected and published the memories about Kondratyuk that had not been previously published $^{2}$. In 2001 the University publishing issued the book Yuriy Kondratyuk (Alexander Shargey) in the Memories of His Contemporaries in Ukrainian translation prepared by Dr. Kocherha, and in 2007 the Memories appeared in Russian [Yuriy Kondratyuk, 2007]. In 2017, on occasion of Yuriy Kondratyuk's one hundred and twentieth anniversary, the third edition of the same book appeared, now as a bilingual edition — in Ukrainian and English [Yuriy Kondratyuk, 2017].

Dr. Kocherha used the great labour and put much her energy translating into Ukrainian the aforesaid academic biography of Yuriy Kondratyuk. It was a complicated task primarily because of difficulty in finding adequate equivalents of Russian technical terms in Ukrainian. In order to prepare a quality Ukrainian translation she had got involved not only Ukrainian philologists, but had also engaged established teachers and scholars in engineering and technology: at the end of the day the activities became the testing ground in order to form Ukrainian technological vocabulary. In 2012 the book was republished: under the same cover reappeared both Russian original, and Ukrainian translation prepared by Dr. Kocherha. The foreword by astronaut Vitaliy Sevastianov was supplemented with the foreword to Ukrainian edition, written by the leading constructor of space technologies, Professor Anatoliy Afanasyyovych Rudenko. In 2017 the Ukrainian translation of the book appeared in a new edition [Datsenko \& Pryschepa, 2017].

Here we should also mention Dr. Nadiya Kocherha own publications that appeared in Ukrainian, Russian, and English: Yuriy Kondratyuk (Alexander Shargey): Philosophy of Life and Creativity as the Way to Attain the Truth (in collaboration with Anatoliy Rudenko) [Kocherha \& Rudenko, 2005]; 'Kondratyuk's Route': Philosophy of the Way 'Through Hardship to the Stars' (in collaboration with Gennadii Aliaiev) [Aliaiev \& Kocherha, 2007]; In the 'Earthly time' and the cosmic space: Y. V. Kondratyuk (O.O. Shargey) - the way to stars (in collaboration with Nataliya Orinich) [Kocherga \& Orinich, 2014]; Yuriyy Kondratyuk: life devoted to cosmic science (in collaboration with Iryna Perederiy and Nataliya Orinich) [Perederiy \& Kocherga \& Orinich, 2015]; Yuriy Kondratyuk (Alexander Shargey): known and unknown (in collaboration with Iryna Perederiy) [Kocherga \& Perederiy, 2017]; Yuriy Kondratyuk's 'Expertise' as an Artefact: Within the Framework of History and Culture (in collaboration with Ludmyla Cherednik) [Cherednyk \& Kocherha, 2017]. One of her papers (in collaboration with Gennadii Aliaiev) A Cosmist-Scientist Yu.V. Kondratyuk (A.I. Shargey): the Hard Way to Immortality also has been published in Philosophy and Cosmology [Aliaiev \& Kocherga, 2009].

It was no accident, perhaps, that Yuriy Kondratyuk became a kind of moral magnet for Dr. Nadiya Kocherha. Their disposition and life-philosophy was to a large extent very alike. Dr. Nadiya Kocherha did not take a fancy to utopian projects, especially those, which could hurt and crush the lives of particular people. On the other hand, it seemed there was nothing impossible or unrealistic for her - which would not be successfully accomplished, if she had only taken it into her hands - whether it was opening of a new department, or the People's museum, or student self-government, or a new speciality... She liked very much

${ }^{2}$ In 2000 - not long before his decease - Anatoliy Datsenko handed to the State Archive of Poltava Region nearly 1300 documents that had been found and collected by him for more than thirty years in research work on Yuriy Kondratyuk's biography. 
those Kondratyuk's words that had preserved in the memoires of his contemporaries: "What a kind of idiotism 'resting'? How is it possible to remain in a complete inactivity for a long time?" [Yuriy Kondratyuk 2007, p. 42]. The same exuberant disposition, ebullient and tireless activity was inherent in Dr. Kocherha. And it was precisely to the point as the book dedicated to the sixtieth anniversary of hers bore the title: "I will never be tired of living and loving"...

May Dr. Nadiya Konstyantynivna Kocherha rest in peace and her memory be eternally blessed!

\section{[4] References}

Aliaiev, Gennadii, and Nadiya Kocherha. 'Kondratyuk's Route': Philosophy of the Way 'Through Hardship to the Stars'. [In Ukrainian]. Visnyk Natshional'noho aviatsiynoho universytetu. Seriya: Filosofiya. Kul'turolohiya: Zbirnyk naukovykh prats'. No. 1 (5): 6-11. - Kyiv: NAU, 2007.

Aliaiev, Gennadii, and Nadiya Kocherha.ACosmist-ScientistYu.V.Kondratyuk(A.I. Shargey): the Hard Way to Immortality. [In Russian]. Filosofia i Kosmologiya 2009: Nauchnoteoreticheskiy sbornik. Mezhdunarodnoe filosofsko-kosmologicheskoe obschestvo; Oleg Bazaluk (chief ed.): 275-287. Poltava: Poltavs'kyi literator, 2009.

Cherednyk, Ludmyla, and Nadiya Kocherha. Yuriy Kondratyuk's 'Expertise' as an Artefact: Within the Framework of History and Culture. [In Ukrainian]. Istoryko-kul'turna spadschyna: zberezhennya, dostup, vykorystannia: zbirka naukovykh prats'. I. Tiurmenko (ed.). 199-202. Ternopil': Beskydy, 2017.

Datsenko, Anatoliy. Yuriy Kondratyuk (Alexander Shargey): the Son of Ukraine, the Son of Poltava. [In Russian]. Poltava: Poltava, 2000.

Datsenko, Anatoliy, and Vladimir Pryschepa. Yuriy Vasil'evich Kondratyuk. 1897-1942. [In Russian]. Moscow: Nauka, 1997.

Datsenko, Anatoliy, and Vladimir Pryschepa. Yuriy Vasyl'ovych Kondratyuk. 1897-1942; tr. into Ukrainian by N.K. Kocherha. [In Ukrainian]. Poltava: PoltNTU, 2017. 172 p.

Kocherga, Nadiya, and Nataliya Orinich. In the 'Earthly time' and the cosmic space: Y.V. Kondratyuk (O.O. Shargey) - the Way to Stars. The Second International Conference on History and Political Sciences (9th June 2014) Austria, Vienna, 2014. P. 64-71.

Kocherga, Nadiya, and Iryna Perederiy. Yuriy Kondratyuk (Olexandr Shargey): Known and Unknown. [In Ukrainian]. Zbirnyk naukovykh prats'. Seriya: Haluzeve mashynobuduvannia, budivnytstvo. Serhyi F. Pechuhin, ed. No. 1 (48): 5-7. Poltava: PoltNTU, 2017.

Kocherha, Nadiya, and Oleksandr Rudenko. Yuriy Kondratiuk (Olexandr Shargei): Philosophy of Life and Creativity as the Way to Attain the Truth. [In Ukrainian]. Slov'yans 'kyi zbirnyk. Issue IV: 251-267. Poltava: Slov'yans'kyi klub, 2005.

Kocherha, Nadiya. O.D. Zasyad'ko: a Descendant of Zaporizhzhya Cannoneer at the Head of Rocket Technology. [In Ukrainian]. Filosofia i kosmologiya 2010: Nauchnoteoreticheskiy sbornik. Mezhdunarodnoe filosofsko-kosmologicheskoe obschestvo; chief ed. Oleg Bazaluk: 272-282. Poltava: Poltavs'kyi literator, 2010.

Perederiy, Iryna., and Nadiya Kocherga, and Nataliya Orinich. Yuriyy Kondratyuk: life devoted to cosmic science. International Review of Education and Science, 2015. Ottawa, Canada: Ottawa University Press, 2015. No.1. (8), (January-June). Volume II. P. 292-296.

Pistolenko, Iryna. Poltava Museum of Aeronautics and Astronautics: Some Aspects of the 
Founding and Functioning. [In Ukrainian]. Naukovi pratsi istorychnoho facultetu Zaporizhskoho natsional'noho universytetu. Issue 45, vol. 2: 253-255. Zaporizhzhia, 2016.

Pistolenko, Iryna. Poltava Region in Aerospace History. [In Ukrainian]. Poltava: Oriyana, 2009. 250 p.

Revehuk, Viktor, and Nadiya Kocherha. V.H. Korolenko. Civic Activities of the Writer (19171921). [In Ukrainian]. Poltava: Dyvosvit, 2014. 212 p.

Revehuk, Viktor, and Nadiya Kocherha. V. H. Korolenko in Poltava. [In Ukrainian]. Poltava: PoltNTU, 2003. 111 p.

Romanenko, Borys. The Star of Kondratyuk-Shargey. The Fate of a Genius of the Twentieth Century. [In Russian]. - Kaluga, 1998.

Yuriy Kondratyuk (Alexander Shargey) in the Memories of His Contemporaries. Anatoliy Datsenko, Iryna Knysh, Nadiya Kocherga (eds.). [In Russian]. Poltava: PoltNTU, 2007.

Yuriy Kondratyuk (Olexandr Shargei) in the Memories of His Contemporaries. Anatoliy Datsenko, Iryna Knysh, Nadiya Kocherha, Gennadii Aliaiev (eds.); Volodymir Onyschenko (ed. in chief). 3rd ed. rev. and expanded. [In Ukrainian]. Poltava: PoltNTU, 2017. 145 p. 